\title{
VARIASI GENETIK IKAN KERAPU SUNU Plectropomus leopardus F-0 HINGGA F-3 BERDASARKAN MARKA MIKROSATELIT
}

\author{
Sari Budi Moria Sembiring\#, Jhon Harianto Hutapea, dan Haryanti \\ Balai Besar Penelitian dan Pengembangan Budidaya Laut \\ (Naskah diterima: 27 April 2015; Revisi final: 29 Juli 2015; Disetujui publikasi: 2 September 2015)
}

\begin{abstract}
ABSTRAK
Penelaahan keragaman genetik pada induk dan turunan ikan kerapu sunu, Plectropomus leopardus merupakan informasi penting dalam proses pemuliaan melalui seleksi konvensional dan penggunaan marka genetik. Tujuan penelitian ini adalah untuk mendapatkan informasi keragaman genetik ikan kerapu sunu dengan metode marka mikrosatelit untuk mendukung program pemuliaan bagi kepentingan penyediaan induk unggul. Sebanyak 10 sampel dari setiap generasi (F-0, F-1, F-2, F-3) ikan kerapu sunu dianalisis menggunakan empat lokus mikrosatelit (PLL4; PLL08; PLL04; PLL5). Seleksi pada keturunan pertama dan kedua (F-1 dan F-2) dilakukan dengan metode konvensional, yaitu memilih ikan berdasarkan pertumbuhan yang cepat. Setelah mendapatkan marka tumbuh cepat pada ikan turunan kedua, maka seleksi untuk turunan ketiga (F-3) dilakukan dengan aplikasi marka penanda tumbuh cepat. Hasil analisis menunjukkan bahwa polimorfisme alel dari keempat lokus mikrosatelit yang diamati pada empat generasi ikan kerapu sunu menunjukkan tingkat variasi yang tinggi dengan nilai PIC $>0,5$. Keragaman genetik $(\mathrm{Ho} / \mathrm{He})$ mengalami penurunan dari F-0 hingga F-3. Namun demikian, nilai indeks fiksasi $(0,13410)$ menunjukkan bahwa keragaman genetik keempat populasi ikan kerapu sunu adalah tidak berbeda nyata. Dengan demikian, ikan kerapu sunu generasi F-1 hingga F-3 masih layak dijadikan induk dalam mendukung program pemuliaan untuk menghasilkan induk unggul.
\end{abstract}

KATA KUNCI: keragaman genetik, generasi berbeda, ikan kerapu sunu, mikrosatelit

ABSTRACT: Genetic variation of coral trout, Plectropomus leopardus, from F-0 to F-3 based on microsatellite marker. By: Sari Budi Moria Sembiring, Jhon Harianto Hutapea, and Haryanti

\begin{abstract}
Research on genetic variation of broodstock population of coral trout, P. leopardus and its generation is important information in breeding program both by conventional selection and using genetic marker. The aim of this research was to get information about genetic variation on coral trout grouper by using microsatellite marker to support breeding program for preparing superior broodstock. Ten samples from each population (F-0, F-1, F-2, F-3) were analysed by using four microsatellite locus (PLL4; PLL08; PLL04; PLL5). Conventional selection was conducted on first and second generation by choosing fast growth group. Fast growth marker was analysed on selected second generation and this fast growth marker was used to produce third generation. The results showed that allele polymorphism from those four DNA microsatellite locus observed from four coral trout grouper population were highly variation with value of PIC >0.5. Genetic variation (Ho/He) was decreased from F-0 to F-3 population, but fixation index value (0.13410) showed that those all four population of coral trout grouper (F-0, F-1, F-2, F-3) has not significant genetic variation. It means that coral trout grouper from F-1 to F-3 population still reliable in supporting the breeding program to produce good quality broodstock.
\end{abstract}

KEYWORDS: $\quad$ genetic variation, different generation, coral trout grouper, microsatellite

\section{PENDAHULUAN}

Dalam melaksanakan budidaya ikan berkelanjutan, ketergantungan pada induk-induk dari alam harus dikurangi secara bertahap dan digantikan dengan in-

\# Korespondensi: Balai Besar Penelitian dan Pengembangan Budidaya Laut. Jl. Br. Gondol Kec. Gerokgak Kab. Buleleng, Kotak Pos 140, Singaraja, Bali 81101, Indonesia. Tel.: + (0362) 92278 E-mail: moriasembiring@yahoo.co.id duk-induk produksi hatcheri hasil domestikasi yang dilanjutkan dengan program selective breeding (Aliah et al., 2006). Dari hasil penelitian evaluasi keragaman genetik induk ikan kerapu sunu generasi pertama dan turunannya menggunakan metode RFLP mt-DNA menunjukkan adanya penurunan keragaman genetik, namun sangat rendah $(0,09 \%)$; dan ini diduga karena jumlah induk yang sedikit (Sembiring et al., 2012). 
Salah satu cara terbaik untuk mengatasi masalah penurunan keragaman genetik adalah dengan melakukan pemuliaan melalui seleksi dengan penggunaan induk yang sesuai dengan kaidah genetik. Secara umum indikasi dari penurunan kualitas genetik ikan ini ditandai dengan sifat-sifat seperti pertumbuhan lambat dan tingkat kematian tinggi, serta rentan terhadap infeksi penyakit terutama virus, misal VNN dan iridovirus. Sehubungan dengan hal tersebut, telah dilakukan penelitian untuk mengevaluasi keragaman genetik populasi induk kerapu sunu F-0 dan turunannya (F-1, F-2, dan F-3) yang merupakan hasil seleksi individu. Kegiatan ini dilakukan dalam rangka mendukung program pemuliaan ikan kerapu sunu untuk memperoleh induk-induk unggul.

Program pemuliaan ikan kerapu sunu telah dilakukan sejak tahun 2008 dan seleksi yang dilakukan secara konvensional. Dalam program pemuliaan, variabilitas genetik dari suatu populasi dapat diketahui dengan mengevaluasi beberapa sifat pertumbuhan. Apabila suatu sifat mempunyai variabilitas genetik yang tinggi, maka seleksi akan dapat dilakukan pada populasi tersebut. Selain mengetahui nilai variabilitas genetik dalam program pemuliaan, nilai heritabilitas perlu juga untuk diketahui. Dari hasil seleksi pada kerapu sunu F-1 dan F-2 mempunyai nilai rataan panjang total tubuh sebesar $26,64 \mathrm{~cm}$ dan $30,25 \mathrm{~cm}$ dengan nilai heritabilitas $37 \%$ pada populasi $\mathrm{F}-1$, dan $34 \%$ untuk populasi $\mathrm{F}-2$, sedangkan pada populasi F-3 belum diperoleh nilai heritabilitas karena populasi F-3 masih belum mencapai umur 18 bulan. Heritabilitas merupakan gambaran apakah suatu karakter lebih dipengaruhi oleh faktor genetik atau faktor lingkungan, dan sejauh mana sifat tersebut diwariskan pada generasi selanjutnya. Dilihat dari nilai heritabilitas ikan kerapu sunu populasi F-1 dan F-2 yang relatif masih tinggi, maka faktor genetik relatif lebih berperan dibandingkan dengan faktor lingkungan. Oleh karena itu, dilakukan analisis variabilitas genetik populasi F-0 hingga F-3 untuk mengetahui nilai keragaman genetiknya.

Kualitas genetik ikan kerapu sunu dapat dilihat dari keragaman genetik pada populasi induk hingga turunannya. Di antara metode yang ada, yang banyak digunakan untuk menganalisis keragaman genetik adalah melalui penggunaan marka genetik mikrosatelit (SSR/simple sequence repeats). Keunggulan mikrosatelit antara lain adalah memiliki tingkat polimorfisme yang tinggi, kodominan dan bersifat spesifik lokus. Sifat-sifat tersebut dapat membedakan antara individu-individu homozigot dan heterozigot (Liu et al., 2009). Pada lokus mikrosatelit, penurunan heterozigositas merupakan indikasi adanya peningkatan nilai inbreeding (Ferguson, 1995). Selanjutnya Wang et al. (2010) juga mengemukakan bahwa mikrosate- lit adalah penanda DNA yang popular selain karena polimorfik juga mudah dianalisis. Penelitian keragaman genetik pada populasi ikan budidaya laut menggunakan marka mikrosatelit telah banyak dilakukan (Koedprang et al., 2007; Gao et al., 2012; Yan et al., 2013).

Dengan demikian marker genetik mikrosatelit telah dikenal sebagai penanda DNA. Marker genetik mikrosatelit sering disebut sebagai simple sequence repeats (SSRs), short tandem repeats (STRs), atau variable number tandem repeats (VNTR). Marker tersebut digunakan dalam berbagai aplikasi seperti linkage analysis, paternity testing, populasi, dan evolusi genetik.

Tujuan penelitian ini adalah untuk mendapatkan informasi keragaman genetik dari induk (F-0) hingga turunannya (F-1, F-2, dan F-3) pada ikan kerapu sunu dengan metode marka mikrosatelit untuk mendukung program pemuliaan bagi kepentingan penyediaan induk unggul.

\section{BAHAN DAN METODE}

\section{Hewan Uji}

Ikan kerapu sunu dari populasi induk F-0 dan turunannya (F-1, F-2, dan F-3) diambil secara acak sebanyak 10 ekor. Sampel yang diambil adalah bagian sirip ekor dan potongan sirip tersebut disimpan dalam tabung mikro volume 1,5 mL. Ukuran panjang dan bobot dari masing-masing populasi adalah F-0 sebesar $58,6 \pm 4,5 \mathrm{~cm}$ dan $4,67 \pm 1,1 \mathrm{~kg}$; F-1 adalah $50,8 \pm 3,01 \mathrm{~cm}$ dan $2,94 \pm 0,41 \mathrm{~kg}$; F2 adalah $44,48 \pm$ $5,22 \mathrm{~cm}$ dan $1,70 \pm 0,68 \mathrm{~g}$; dan F-3 adalah 10,98 $\pm 0,83$ $\mathrm{cm}$ dan $18,5 \pm 4,01 \mathrm{~g}$.

\section{Ekstraksi DNA}

Jaringan sirip ekor dari masing-masing sampel individu diekstraksi menggunakan DNEasy (DNA kit extraction) dari Qiagen. Protokol ekstraksi DNA mengikuti langkah kerja yang diberikan oleh DNEasy, yaitu menggunakan spin column method. DNA genomik hasil ekstraksi kemudian disimpan di freezer $-20^{\circ} \mathrm{C}$ hingga akan digunakan dalam amplifikasi PCR.

\section{Amplifikasi DNA}

Proses amplifikasi DNA untuk tiap sampel membutuhkan volume reaksi sebesar $25 \mu \mathrm{L}$ dengan master mix yang digunakan adalah Top Taq master mix (Qiagen). Amplifikasi dilakukan dengan menambahkan $3 \mu \mathrm{L}$ DNA genom hasil ekstraksi bersama dengan masing-masing $1,25 \mu \mathrm{L}$ dari 10 pmol primer mikrosatelit forward dan reverse (Tabel 1), $12.5 \mu \mathrm{L}$ mastermix dan $7.0 \mu \mathrm{L} \mathrm{ddH}_{2} \mathrm{O}$. Proses amplifikasi dilakukan dengan menggunakan T-personal Thermocycler (Biometra) dengan siklus amplifikasi berupa inisiasi de- 
Tabel 1. Primer mikrosatelit dan suhu annealing yang digunakan untuk analisis keragaman genetik menggunakan mikrosatelit terhadap empat generasi berbeda pada ikan kerapu sunu P. leopardus (Ding et al., 2009)

Table 1. Microsatellite primer and annealing temperature that used to analyse genetic variation using microsatellite on four different generation of coral trout grouper P. leopardus (Ding et al., 2009)

\begin{tabular}{cccc}
\hline $\begin{array}{c}\text { Primer } \\
\text { Primer }\end{array}$ & $\begin{array}{c}\text { Motif pengulangan } \\
\text { Repeat sequence }\end{array}$ & $\begin{array}{c}\text { Urutan basa } \\
\text { Base sequence }\left(5^{\prime}-3^{\prime}\right)\end{array}$ & $\begin{array}{c}\text { Suhu annealing } \\
\text { Annealing temperature }\left({ }^{\circ} \mathrm{C}\right)\end{array}$ \\
\hline PLL4 & $(\mathrm{GT})_{17}$ & $\begin{array}{c}\text { F: FAM-ACCCATCCACCTCCCATCCC TAA } \\
\text { R: TGTCTGCGTGCTCCAATCTATCT }\end{array}$ & 56 \\
\hline PLL08 & $(\mathrm{TG})_{9} . .(\mathrm{CT})_{5} . .(\mathrm{CA})_{23}$ & $\begin{array}{c}\text { F: TET-CCTCCTCTTCATTAGGGACATTTG } \\
\text { R: GCCCAGCACCTACGCCAGTTTTAT }\end{array}$ & 56 \\
\hline PLL04 & $(\mathrm{CA})_{19} . .(\mathrm{TG})_{23}$ & $\begin{array}{c}\text { F: HEX- GAAAGTAAAAATACAGAG ACGGAG } \\
\text { R: TCAAATACATCCCCCTATCTCCA }\end{array}$ & 56 \\
\hline PLL5 & $(\mathrm{CA})_{21}$ & $\begin{array}{r}\text { F: HEX-GCTGCCATTTATTTCGGCTTGA } \\
\text { R: TTCAATTTAGCTCCACTTGCTT }\end{array}$ & 60 \\
\hline
\end{tabular}

naturasi pada suhu $95^{\circ} \mathrm{C}$ selama lima menit, dilanjutkan dengan 35 siklus masing-masing denaturasi pada suhu $94^{\circ} \mathrm{C}$ selama 30 detik, annealing pada suhu yang direkomendasikan sesuai Tabel 1 selama 30 detik dan ekstensi pada suhu $72^{\circ} \mathrm{C}$ selama 30 detik. Perpanjangan terakhir adalah pada suhu $72^{\circ} \mathrm{C}$ selama lima menit, dan suhu penyimpanan sampel sementara $4^{\circ} \mathrm{C}$. Pengecekan hasil amplifikasi PCR dilakukan dengan elektroforesis menggunakan gel agarose 1,5\% dalam $1 \mathrm{x}$ buffer TBE.

Penelitian ini menggunakan empat lokus mikrosatelit (Tabel 1) sebagai penanda molekul. Lokus tersebut dipilih berdasarkan rekomendasi Ding et al. (2009) karena dapat menunjukkan polimorfisme pada ikan kerapu sunu. Dari masing-masing lokus tersebut pada posisi forward (F) yang digunakan dengan probe (FAM, HEX, dan TET) terlebih dahulu. Amplikon yang dihasilkan selanjutnya diseparasi menggunakan mesin Sequencer ABI Prism yang dilakukan di $1^{\text {st }}$ Base Singapore. Pada saat separasi dilakukan multiplex pada dua lokus yang mempunyai target yang berbeda, yaitu lokus PLL04 (315 bp) dan PLL5 (350 bp).

\section{Analisis Data}

Ukuran alel hasil separasi sequencer selanjutnya dianalisis dengan program GeneMapper versi 4.0. Ukuran pita DNA kemudian diolah dalam bentuk Microsoft Excel dan diubah dengan menggunakan software CREATE 3.7 (Coombs et al., 2008) ke format yang sesuai dengan software Arlequin versi 3.5.

Penghitungan data meliputi nilai persentase keragaman genetik (nilai kelimpahan alel, keragaman alel, kandungan informasi polimorfik (polymorphic in- formation content, PIC), nilai heterozigositas teramati (Ho), dan heterozigositas harapan (He) melalui AMOVA (analysis of molecular variance) dengan menggunakan software Arlequin versi 3.5 (Excoffier \& Lischer, 2010).

\section{HASIL DAN BAHASAN}

Hasil optimasi sebanyak lima lokus, diperoleh empat lokus, yaitu PLL4, PLL08, PLL04, dan PLL5 yang memunculkan sifat polimorfisme alel pada ikan kerapu sunu. Empat set lokus mikrosatelit tersebut digunakan dalam penelitian ini berhasil mengamplifikasi fragmen DNA dengan polimorfik yang tinggi. Hasil analisis keragaman genetik menunjukkan bahwa keragaman genetik antar induk F-0 dan turunan F-1, F-2, dan F-3 ikan kerapu sunu dapat tergambarkan dengan baik. Hasil analisis jumlah alel, PIC, nilai heterozigositas teramati (Ho), dan heterozigositas harapan (He) ditampilkan pada Tabel 2.

Pada Tabel 2 terlihat bahwa jumlah alel pada ikan kerapu sunu F-0 menunjukkan kisaran 9-12 lokus. Sementara itu, pada generasi berikutnya jumlah alel semakin berkurang, berkisar 4-9 pada F-1, 6-9 pada F-2, dan 3-7 lokus pada F-3. Namun demikian, nilai heterozigositas masih relatif tinggi pada masing-masing lokus yang digunakan untuk analisis. Pada ikan kerapu sunu F-0, nilai rata-rata heterozigositas 0,715 ; sedangkan nilai rata-rata heterozigositas pada F-1 sebesar 0,613 . Nilai rata-rata heterozigositas pada turunan F-2 dan F-3 berturut turut sebesar 0,841 dan 0,896; dan lebih tinggi daripada F-0 dan turunan F-1. Hal ini menunjukkan bahwa terjadi aliran gen (gene flow) yang dapat menambah alel yang baru sehingga akan mengubah frekuensi alel. 
Tabel 2. Keragaman genetik induk F-0 dan turunan F-1, F-2, dan F-3 ikan kerapu sunu yang dianalisis dengan empat lokus mikrosatelit

Table 2. Genetic variation of coral trout grouper F-0 generation, and its progenies F-1, F-2, and F-3 analyzed with four microsatellite locus

\begin{tabular}{|c|c|c|c|c|c|}
\hline $\begin{array}{l}\text { Keturunan } \\
\text { Generation }\end{array}$ & $\begin{array}{l}\text { Lokus } \\
\text { Loci }\end{array}$ & $\begin{array}{c}\text { Jumlah alel } \\
\text { Number of allele }\end{array}$ & Ho & $\mathrm{He}$ & PIC \\
\hline \multirow{5}{*}{$\mathrm{F}-\mathbf{0}$} & PLL4 & 10 & 0.727 & 0.792 & 0.740 \\
\hline & PLL08 & 10 & 0.667 & 0.902 & 0.850 \\
\hline & PLL04 & 12 & 0.750 & 0.920 & 0.871 \\
\hline & PLL5 & 9 & 0.714 & 0.912 & 0.831 \\
\hline & \multicolumn{2}{|c|}{ Rata-rata (Average) } & 0.715 & 0.882 & 0.823 \\
\hline \multirow{5}{*}{ F-1 } & PLL4 & 4 & 0.417 & 0.424 & 0.371 \\
\hline & PLL08 & 9 & 0.667 & 0.855 & 0.800 \\
\hline & PLL04 & 6 & 0.700 & 0.789 & 0.711 \\
\hline & PLL5 & 6 & 0.667 & 0.667 & 0.590 \\
\hline & \multicolumn{2}{|c|}{ Rata-rata (Average) } & 0.613 & 0.684 & 0.618 \\
\hline \multirow{5}{*}{ F-2 } & PLL4 & 9 & 0.917 & 0.866 & 0.810 \\
\hline & PLL08 & 6 & 0.667 & 0.739 & 0.670 \\
\hline & PLL04 & 6 & 0.778 & 0.797 & 0.713 \\
\hline & PLL5 & 6 & 1,000 & 0.700 & 0.609 \\
\hline & \multicolumn{2}{|c|}{ Rata-rata (Average) } & 0.841 & 0.776 & 0.701 \\
\hline \multirow{5}{*}{ F-3 } & PLL4 & 5 & 1,000 & 0.710 & 0.630 \\
\hline & PLL08 & 5 & 0.917 & 0.797 & 0.723 \\
\hline & PLL04 & 7 & 0.667 & 0.869 & 0.797 \\
\hline & PLL5 & 3 & 1,000 & 0.627 & 0.516 \\
\hline & \multicolumn{2}{|c|}{ Rata-rata (Average) } & 0.896 & 0.751 & 0.667 \\
\hline
\end{tabular}

Hal yang sama terjadi dengan nilai heterozigositas harapan pada populasi induk F-0 dan populasi turunannya F-1, F-2, dan F-3. Semua lokus mikrosatelit (PLL4; PLL08; PLL04) yang digunakan untuk analisis menunjukkan adanya penurunan nilai heterosigositas $(\mathrm{Ho}<\mathrm{He})$. Pada lokus mikrosatelit, penurunan heterozigositas merupakan indikasi adanya peningkatan nilai inbreeding (Hauser \& Seeb, 2008). Selanjutnya Pan \& Jinzeng (2010) menyatakan bahwa jika nilai Ho lebih rendah dari He, menunjukkan telah terjadi perkawinan dalam kelompok (endogamy degree) sebagai hasil dari proses seleksi yang intensif. Berdasarkan protokol seleksi dari kerapu, jumlah induk yang digunakan seharusnya 50-100 ekor, namun kenyataannya pada seleksi kerapu sunu, jumlah induk dari F-0 sampai F-2 tidak sesuai dengan protokol seleksi sehingga menyebabkan terjadi peningkatan inbreeding. Oleh karena itu, untuk mempertahankan nilai keragaman genetik maka program selanjutnya adalah memperbanyak jumlah induk yang dipijahkan untuk pembentukan generasi berikutnya.
Pada keempat lokus yang digunakan menghasilkan sifat alel yang polimorfik. Sifat polimorfik alel DNA ikan kerapu sunu yang dihasilkan memiliki ukuran pasangan basa (base pairs/bp) yang berbeda-beda pada masing-masing lokus. Ukuran alel DNA dan jumlah alel yang diperoleh pada masing-masing lokus yang diamati pada populasi induk F-0, dan turunan F-1, F-2, dan F-3 ikan kerapu sunu disajikan pada Tabel 3 .

Polimorfisme alel dari keempat lokus mikrosatelit DNA yang diamati pada empat populasi kerapu sunu secara umum menunjukkan tingkat keragaman yang tinggi yaitu antara 14-17 alel per lokus (Tabel 3). Keragaman alel dari induk (F-0) dan turunan (F-1, F-2, F-3) ikan kerapu sunu relatif tidak berbeda antar lokus. Dari 40 ekor sampel ikan kerapu sunu yang dianalisis keragamannya menggunakan empat lokus mikrosatelit (PLL4; PLL08; PLL04; dan PLL5) dapat teridentifikasi sebanyak 61 alel yang mempunyai variasi ukuran berat molekul. Pada populasi induk F-0 terdapat nilai rataan alel 10,25 $\pm 1,26$ yang merupakan 
Tabel 3. Ukuran fragmen DNA (bp) dan jumlah alel mikrosatelit masing-masing lokus pada populasi induk F-0 dan turunan F-1, F-2, dan F-3 ikan kerapu sunu, P. leopardus

Table 3. Number and size of DNA microsatellite fragment (bp) from each loci of coral trout grouper, P. leopardus F-0 and its progenies F-1, F-2, and F-3 population

\begin{tabular}{|c|c|c|c|c|c|c|}
\hline \multirow{2}{*}{$\begin{array}{l}\text { Lokus } \\
\text { Loci }\end{array}$} & \multirow{2}{*}{$\begin{array}{l}\text { Fragmen } \\
\text { Fragment } \\
\text { (bp) }\end{array}$} & \multirow{2}{*}{$\begin{array}{l}\text { Keragaman alel } \\
\text { Variation of allele }\end{array}$} & \multicolumn{4}{|c|}{$\begin{array}{l}\text { Jumlah alel pada populasi ikan kerapu sunt } \\
\text { Number of allele on population of coral trout }\end{array}$} \\
\hline & & & F-0 & F-1 & F-2 & F-3 \\
\hline PLL4 & $240-265$ & 15 & 10 & 4 & 9 & 5 \\
\hline PLL08 & 286-338 & 14 & 10 & 9 & 6 & 4 \\
\hline PLL04 & $307-349$ & 17 & 12 & 6 & 6 & 7 \\
\hline PLL5 & 353-392 & 15 & 9 & 6 & 6 & 3 \\
\hline $\begin{array}{l}\text { Total alel } \\
\text { Total number of allele }\end{array}$ & & 61 & 41 & 25 & 27 & 19 \\
\hline $\begin{array}{l}\text { Kisaran jumlah alel } \\
\text { Range number of allele }\end{array}$ & & $14-17$ & $9-12$ & $4-9$ & $6-9$ & $3-7$ \\
\hline $\begin{array}{l}\text { Proporsi lokus polimorfik } \\
\text { Polymorphic locus proporsion }\end{array}$ & & - & 0.18 & 0.12 & 0.16 & 0.38 \\
\hline $\begin{array}{l}\text { Rataan jumlah alel per lokus } \\
\text { Average of allele number per loci }\end{array}$ & & 15.25 & 10.25 & 6.25 & 6.75 & 4.75 \\
\hline $\begin{array}{l}\text { Standar deviasi } \\
\text { Standard deviation }\end{array}$ & & 1,258 & 1,258 & 2,062 & 1,500 & 1,633 \\
\hline
\end{tabular}

jumlah alel tertinggi, sedangkan pada populasi F-1 mempunyai rataan alel $6,25 \pm 2,06$. Hasil pengamatan terhadap alel rataan pada turunan F-2 sebanyak $6,75 \pm 1,50$ dan alel dengan rataan 4,75 $\pm 1,63$ diperoleh pada populasi turunan F-3. Fenomena jumlah alel yang tinggi pada ikan kerapu sunu populasi induk F-0 karena variasi genetik pada lokus-lokus mikrosatelit tersebut sangat beragam yaitu rataan keragaman gen pada semua lokus 0,882 . Keragaman yang tinggi pada lokus-lokus mikrosatelit ini dipengaruhi oleh tingkat mutasi basa nukleotida. Menurut Portnoy et al. (2010), DNA mikrosatelit memiliki laju perubahan basa nukleotida tinggi yang disebabkan adanya perubahan jumlah ulangan dari urutan basa bergandengan mencapai 10-3/gamet/generasi.

Selain berdasarkan kelimpahan alel, pengamatan terhadap nilai PIC pada semua lokus yang digunakan bersifat informatif, mengingat PIC merupakan nilai untuk memperkirakan tinggi dan rendahnya tingkat informasi suatu penanda genetik. Hal ini terbukti dari nilai PIC pada empat lokus yang digunakan berkisar antara 0,638-0,773 (Tabel 3). Nilai PIC yang lebih tinggi dari ambang batas 0,5 menunjukkan bahwa marka genetik yang digunakan bersifat informatif (Agbebi et al., 2013). Sementara itu, nilai polimorfik yang tinggi dapat diperoleh jika jumlah rata-rata alel yang terdeteksi cukup tinggi. Menurut Tautz et al. (2010), untuk penanda genetik, lokus dengan heterozigosity $>0,7$ secara umum dikatakan sebagai pe- nanda polimorfik tinggi. Berdasarkan Tabel 3, terlihat bahwa dari keempat lokus yang digunakan memberikan nilai He $>0,7$ sehingga keempat lokus tersebut memberikan tingkat informasi yang tinggi.

Walaupun terjadi penurunan keragaman genetik dari populasi induk F-0 kepada turunan berikutnya, namun berdasarkan hasil analisis AMOVA dengan software Arlequin versi 3.5 (Excoffier \& Lischer, 2010) masih menunjukkan adanya sebaran keragaman genetik di dalam populasi yang tinggi atau dengan kata lain bahwa keragaman genetik induk (F-0) terhadap turunan F-1, F-2, dan F-3 kerapu sunu mempunyai kemiripan yang tinggi dalam populasi tersebut (Tabel 4). Dengan demikian populasi turunan F-1, F-2, dan F-3 ikan kerapu sunu hasil seleksi mempunyai keunggulan karakter secara genotipe relatif sama dengan induk F-0 yang berasal dari alam.

Indeks fiksasi $\left(\mathrm{F}_{\text {ST }}\right)$ merupakan ukuran diferensiasi genetik suatu populasi dengan nilai berkisar dari nol sampai satu. Nilai nol menunjukkan bahwa tidak ada perbedaan secara genetik dari populasi-populasi yang diamati, sedangkan nilai 1,0 diartikan bahwa ada perbedaan karakter genetik yang sangat jelas. Pada penelitian ini diperoleh nilai $F_{S T}$ sebesar 0,13410 . Hal tersebut menunjukkan bahwa keempat populasi ikan kerapu sunu yang diteliti memiliki perbedaan keragaman genetik yang sedikit. Perbedaan keragaman genetik yang sedikit menandakan bahwa populasi ikan kerapu sunu F3 masih layak dijadikan induk 
Tabel 4. Analysis of molecular variance (AMOVA) dari populasi induk F-0 dan turunan F-1, F-2, dan F-3 kerapu sunu, P. leopardus menggunakan empat lokus mikrosatelit

Table 4. Analysis of molecular variance (AMOVA) from broodstock (F-0) and F-1, F-2, F-3 coral trout grouper, P. leopardus population by using four microsatellite locus

\begin{tabular}{cccc}
\hline $\begin{array}{c}\text { Sumber variasi } \\
\text { Source of variation }\end{array}$ & $\begin{array}{c}\text { Jumlah square } \\
\text { Sum of squares }\end{array}$ & $\begin{array}{c}\text { Komponen varian } \\
\text { Variance components }\end{array}$ & $\begin{array}{c}\text { Persentase variasi } \\
\text { Percentage variation (\%) }\end{array}$ \\
\hline $\begin{array}{l}\text { Antar populasi } \\
\text { Among populations } \\
\text { Di dalam populasi } \\
\text { Within populations }\end{array}$ & 20.021 & 0.23811 & 13.41 \\
\hline Total & 126.897 & 1.53753 & 86.59 \\
\hline Indeks fiksasi $\left(\mathrm{F}_{\mathrm{ST}}\right)$ / Fixation indexes $=0.13410$ & 1.77564 \\
\hline
\end{tabular}

karena sebanyak $86,59 \%$ variasi genetik terdapat di dalam masing-masing populasi. Dengan demikian populasi induk F-0 dan turunan F-1, F-2, F-3 kerapu sunu, mempunyai keragaman genetik yang masih tergolong sama atau memiliki kemiripan genetik yang cukup tinggi satu dengan lainnya.

\section{KESIMPULAN}

Keragaman genetik populasi induk (F-0) dan turunan F-1, F-2, dan F-3 kerapu sunu P. leopardus menunjukkan nilai yang relatif masih tinggi. Keragaman genetik tersebut tersebar sebanyak $86,59 \%$ di dalam populasi (within populations) dan 13,41\% tersebar di antara populasi (among populations). Nilai indeks fiksasi menunjukkan bahwa populasi induk dan turunannya ikan kerapu sunu hanya memiliki perbedaan keragaman genetik sebesar $13,41 \%$. Dengan demikian populasi turunan F-1, F-2, dan F-3 kerapu sunu hasil seleksi mempunyai keunggulan karakter secara genotipe seperti induk F-0 yang berasal dari alam.

\section{DAFTAR ACUAN}

Aliah, R.S., Wahidah, Sumantadinata, K., Nugroho, E., \& Carman, O. (2006). Karakterisasi genetik ikan kerapu tikus, Cromileptes altivelis generasi pertama hasil program domestikasi. Jurnal Akuakultur Indonesia, 5(1), 87-95.

Agbebi, O.T., Deborah, E.I., \& Adebambo, A.O. (2013). Preliminary characterization of genetic strains in clariid species, Clarias gariepinus and Heterobranchus bidorsalis using microsatellite markers. African Journal of Biotechnology, 12(4), 364-369.

Coombs, J.A., Letcher, B.H., \& Nislow, K.H. (2008). Create: A software to create input files from diploid genotypic data for 52 genetic software programs. Molecular Ecology Resources, 8, 578-580.

Ding, S.X., Zeng, H.S., Wang, Y., Pan, Y., \& Feng, S.X. (2009). Characterization of eight polymorphic microsatellite loci for the leopard coral grouper (Plectropomus leopardus). Molecular Ecology Resources, 9(6), 1485-1487.

Excoffierd, L., \& Lischer, H.E. (2010). Arlequin suite ver 3.5: a new series of programs to perform population genetic analysis under Linux and Windows. Mol. Ecol. Resour., 10, 564-567.

Gao, C., Le, W., Bin, F., Sen, Y., Zining, M., \& Haoran, L. (2012). Isolation and characterization of microsatellite markers from the Brown-marbled grouper, Epinephelus fuscoguttatus. Journal of The World Aquaculture Society, 43(3), 442-446.

Hauser, L., \& Seeb, J.E. (2008). Advances in molecular technology and their impact on fisheries genetics. Fish and Fisheries, 9, 473-486.

Koedprang, W., Uthairat, N.N., Masamichi, N., \& Nobuhiko, T. (2007). Evaluation of genetic diversity of eight grouper species, Epinephelus spp. based on microsatellite variations. Fisheries Science, 73, 227-236.

Liu, F., Xia, J.H., Bai, Z.Y., Fu, J.J., Li, J.L., \& Yue, G.H. (2009). High genetic diversity and substantial population differentiation in grass carp, Ctenopharyngodon idella revealed by microsatellite analysis. Aquaculture, 297, 51-56.

Pan, G., \& Jinzeng, Y. (2010). Analysis of microsatellite DNA markers reveals no genetic differentiation between wild and hatchery populations of Pacific threadfin in Hawaii. Int. J. Biol. Sci., 6(7), 827-833.

Portnoy, D.S., Mcdowell, J.R., Heist, E.J., Musick, J.A., \& Graves, J.E. (2010). World phylogeography and male-mediated gene flow in the sandbar shark, Carcharhinus plumbeus. Molecular Ecology, 19, 19942010.

Sembiring, S.B.M., Suwirya, K., Melianawati, R., \& Haryanti. (2012). Evaluasi keragaman genetik induk ikan kerapu sunu, Plectropomus leopardus F-1 
dan turunannya (F-2) dengan penanda Mt-DNA. J. Ris. Akuakultur, 7(3), 337-343.

Tautz, D., Ellegren, H., \& Weigel, D. (2010). Next generation molecular ecology. Molecular Ecology, 19, 1-3.

Wang, J.L., Brekke, P., Huchard, E., Knapp, L.A., \& Cowlishaw, G. (2010). Estimation of parameters of inbreeding and genetic drift in populations with overlapping generations. Evolution, 64, 17041718.

Yan M.K., Yvonne, S.D.M., \& Ka, H.C. (2013). Isolation and characterization of microsatellite markers from the camouflage grouper, (Epinephelidae). Conservation Genet. Resour., 5, 1129-1132. 